\title{
Amelioration of Cisplatin Induced Sexual Toxicity on Male Rats by Using Fortified of Flat Bread with Moringa Oleifera
}

\author{
Ali Monahi Nazal Al Shammari ${ }^{1}$ and Hanaa F. El-Mehiry ${ }^{2}$
}

${ }^{1}$ Faculty of Home Economics, the Public Authority for Applied Education and Training, Kuwait

${ }^{2}$ Department of Home Economics, Faculty of Specific Education, Mansoura University, Egypt

\section{ABSTRACT}

$T$

he study aim to investigat the effect of fortification of flat bread with moringa oleifera aganist cisplatin induced sexual toxicity in male rats and evaluates the sensory characteristics and the nutritive value of the fortified bread prepared against cisplatin. Chemical composition of flat bread, flat bread fortified by moringa powder and oil were determined. To induce sexual toxicity, male rats were given cisplatin by $(12 \mathrm{mg} / \mathrm{kg}$ body weight). Thirty five male rats were classified into seven groups ( $n=5)$. The first group was kept as negative control group, while the other six groups were injected with cisplatin to induce toxicity in various experimental animals; one of those groups was fed on basal diet only and served as positive control group (G2). The third group (G3) was fed on basal diet and treated with control flat bread (100\% wheat flour). The fourth and fifth (G4\&G5) groups were fed on basal diet containing fortified flat bread with $10 \%$ \& $15 \%$ moringa powder respectively. The sixth and seventh $(G 6 \& G 7)$ were fed on basal diet containing fortified flat bread with $5 \mathrm{ml}$ and $10 \mathrm{ml}$ moringa oil respectively. Results: The results revealed that rats consumed fortified flat bread with moringa powder and oil showed significant increases in follicle stimulating hormone level (FSH), and luteinizing hormone (LH), compared with the positive control. Administration of moringa powder and oil improved kidney function, liver enzymes and antioxidant parameters in male rats. In the current study, the protective effect of moringa powder and oil against cisplatin induced sexual toxicity in rats was improved. Conclusions: Moringa powder and oil may be used to prevent toxicity during chemotherapeutic treatment with cisplatin.

Key words: Moringa Oleifera-Flat Bread-Cisplatin-Sexual Toxicity-Nephrotoxicity 


\section{INTRODUCTION}

Cisplatin is one of the most commonly used chemotherapy drugs against cancer. It is especially effective in the treatment of testicular cancers also it is effective against carcinoma of many other tissues, including those of lung, head, neck, cervix, and ovary. Cleary, (2007). Historically, cisplatin is thought to exert its primary cytotoxic effects via formulation of platinum-DNA adducts. Galea \& Murray, (2002) and Myers \&Shetty, (2008). Miller, et al., (2010) reported that cisplatin is an effective to treat the solid tumors, but it is accompanied with nephrotoxicity.

Flat bread is made throughout most of the world. Examples are tortilla, chapati, pita, parotta, yufka, tandoori roti, sangak, balady, barbari, taftoon, lavash, ciabatta, baati, bafla, phulka, kulcha and gyro bread Coskuner and Karababa, (2005). Flat bread is characterize lower specific volumes, high crust and crumb ratio than flat bread. The unleavened flat breads have shorter fermentation period in comparison to pan bread. They have different production conditions coming from higher baking temperature and shorter baking time Coskuner et al., (1999).

Moringa oleifera family Moringaceae and commonly known Drumstick tree, is indigenous to Northwest India. Most of the parts of the plant possess antimicrobial activity. They are well famous for their pharmacological actions too and are used for the traditional treatment of hypercholesterolemia and hyperglycemia, also as a nutritional supplement Babu and Chaudhuri, (2005) and Asare, et al., (2012).

The major saturated fatty acids present in the seeds are palmitic, stearic, and benic acids. Oleic acid is the main unsaturated fatty acid (67.9$70.0 \%$ ), whose high 
Ali Monahi Nazal Al Shammari \& Hanaa F. El-Mehiry

concentration is desirable in terms of nutrition and stability during cooking and frying Abdulkarim, et al., (2005). Moreover, as a natural source of benic acid, the moringa oleifera oil has been used as a solidifying agent in margarines and other foodstuffs containing solid and semisolid fat, therefore eliminating hydrogenation processes. Moringa oleifera seed oil is highly resistant to oxidative rancification, which can explain its several industrial uses such as in the production of cosmetics and cooking oil Soliva, et al., (2005).

The aim of this study: this study aims to demonstrate the toxicity caused by cisplatin may be prevented by using flat bread fortified with moringa powder and oil treatment. Thus, it was judged that coadministration of moringa powder and oil with cisplatin may be useful to minimised the negative effects of cisplatin nephrotoxicity, hepatotoxicity, sexual toxicity, and oxidation on male rats.

\section{MATERIALS \& METHODS}

\section{Material:}

Moringa (Moringa Oleifera): leaves and oil were obtained from the Agricultural Research Center, Dokki, Giza, Egypt. Wheat flour (72\% extraction), milk, yeast, butter, oil and salt were obtained from local market.

\section{Drugs and chemicals:}

Cisplatin solution ${ }^{\odot}$ (Platinol AQ) was obtained from Sigma Chemical Co. (St Louis, Mo, USA).

Kits: Kits used to determine the biochemical analysis were obtained from the Egyptian American Company for laboratory service and supplied by Alkan Company.

Rats: Thirty five male rats, 911 weeks old male Sprague Dawley rats weighing $180 \pm 10$ g. were obtained from Laboratory of Animal Colony, Helwan, Egypt. The animals were allocated in plastic cages with metallic stainless covers. Rats were fed the basal diet for 7 days before the beginning of the experiment for adaptation. The basal diet comprised of 
casein $(200 \mathrm{~g} / \mathrm{kg})$, corn starch $(497 \mathrm{~g} / \mathrm{kg})$, sucrose $(100 \mathrm{~g} / \mathrm{kg})$, cellulose $(30 \mathrm{~g} / \mathrm{kg})$, corn oil $(50 \mathrm{~g} / \mathrm{kg})$, minerals mixture $(100 \mathrm{~g} / \mathrm{kg})$, vitamins mixture $(20 \mathrm{~g} / \mathrm{kg})$ and DL-methionine $(3 \mathrm{~g} / \mathrm{kg})$ prepared according to Reeves et al., (1993). Animals were subjected to a 12 hours light and 12 hours dark schedule.

\section{Methods:}

\section{Chemical analysis of raw} materials and flat bread:

Moisture, protein, fat, ash, and fibers were determined according to the method outlined in A.A.C.C. (2000). Total carbohydrates were determined by difference as mentioned by Abd El-Latif, (1990).

\section{HPLC analysis of} polyphenols and flavonoids:

HPLC analysis of extracts was performed using an Agilent 1200 chromatograph equipped with a PDA model G1315B, a Bin pump model G1312A, an autosampler model G1313A and a RR Zorbax Eclipse Plus
C18 column (1.8 $\mu \mathrm{m}, 150$ $\mathrm{mm} \times 4.6 \mathrm{~mm})$. The mobile phase A was $0.2 \%$ formic acid in water and the mobile phase $\mathrm{B}$ was acetonitrile. Elution was performed at $0.95 \mathrm{~mL}$ min-1 with the following gradient program of solvent B: 0-20 min, 5-16 \%; 20-28 min, 16$40 \%$; 28-32 min, 40-70\%; 32-36 min, 70-99 \%; 36-45 min, $99 \%$ and 45-46, min. 99-5 \%.30 The injection volume was $10 \mu \mathrm{L}$. Wavelengths of $280 \mathrm{~nm}$ (for flavan-3-ols and benzoic acid derivatives) and $360 \mathrm{~nm}$ (for flavonols and cinnamic acid derivatives) were selected for detection according to (Merfort, et al., 1997).

\section{Preparation of flat bread:}

Wheat flour was mixed with salt, water and various other ingredients to form dough. Bakers' yeast or sourdough is also used in leavened products. Dough mixing involves the combining and blending of the formula ingredients (Hoseney, 1988). Flat bread are made of unleavened dough without 
Ali Monahi Nazal Al Shammari \& Hanaa F. El-Mehiry

fermentation. Since it is not fermented, it was agreed that it should have a resting time of 30 to $60 \mathrm{~min}$. Then it was baked it in special oven under high temperature varying 350550o $\mathrm{C}$ for a quality flat bread production (Quail et al., 1990). Some flat bread is baked on an overheated hot plate with different shapes of dough.

Types of flat bread were classified into:

1-Control flat bread: was made from $100 \%$ wheat flour $(72 \%$ exertion) without any fortification.

2-Different Formulas: Were made from a mixture of wheat flour and moringa powder and oil at various levels (10\%,

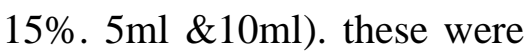
prepared at Agriculture Research Center according to the common method described by Khorshid, et al., (1989).

\section{Sensory evaluation:}

Evaluations of the flat bread (fortified and un-fortified bread with moringa) were carried out according to (Molander, 1960).

\section{Experimental design:}

All rats were fed the basal diet for two weeks prior to commencement of the experiment for adaptation. Then they were divided into seven main groups (5 rats each) and fed the experimental diets for thirty five days. The first group (G1) was kept as negative control group and fed on the basal diet only, while the other six groups $(\mathrm{G} 2, \mathrm{G} 3$, G4, G5, G6 and G7) were injected intraperitoneally into rats with LD50 of cisplatin in a dose of $12 \mathrm{mg} / \mathrm{kg}$ body weight according to Atssahin et al., (2006), to induce toxicity in various animal studies. One of these groups fed on basal diet only and served as positive control group (G2). The third group (G3) fed on standard diet and treated with control flat bread (100\% wheat flour). The fourth and fifth (G4 and G5) groups were fed on basal diet containing fortified flat bread with $10 \%$ \& $15 \%$ 
Ali Monahi Nazal Al Shammari \& Hanaa F. El-Mehiry

moringa powder respectively. The sixth and seventh (G6 and G7) were fed on basal diet containing fortified flat bread with $5 \mathrm{ml} \& 10 \mathrm{ml}$ moringa oil respectively. During the experimental period, the quantities of diet, which were consumed and / or wasted, were weighed daily. In addition, rat's weight was recorded weekly, to determine food intake and body weight gain.

\section{Blood Sampling:}

At the end of the experimental period, the rats were fasted overnight then the rats were anaesthetized and sacrificed and blood samples were collected in non heparinised tubes from the aorta. The blood samples were centrifuged for 15 minutes at $3000 \mathrm{rpm}$ to separate the serum. The serum was carefully separated into dry clean Wassermann tubes by using a Pasteur pipette and kept frozen at $-20^{\circ} \mathrm{C}$ till analysis.
Biochemical analysis of serum:

Uric acid was determined in the serum according to the method described by Fossati and Principe, (1982). Urea was determined according to Patton and Crouch, (1977). Creatinine was determined according to Bartels, et al., (1972).

Aspartate aminotransferase (AST) and alanine aminotransferase (ALT) were assayed by Reitman and Frankel (1957), while alkaline phosphatase (ALP) was assayed by Kind and King, (1954). Serum total cholesterol, triglycerides, high density lipoprotein and low density lipoprotein were determined by the methods of Roeschlau, et al., (1974); Fossati and Principe, (1982), respectively.

\section{Determination of serum sexual hormonal profile:}

Serum testosterone, and follicle stimulating hormone levels (FSH) in the serum were determined by an enzymelinked immunosorbent assay 
Ali Monahi Nazal Al Shammari \& Hanaa F. El-Mehiry

(ELISA) using commercial kits as described by Wilke and Utley (1987)and Ballester et al., (2004). Luteinizing hormone (LH) was quantified

by

radioimmunoassay according to the method described by Schams and Karg (1969).

Determination of serum antioxidant parameters:

Superoxide dismutase (SOD) activity, Total antioxidants capacity (TAC), and Malondialdehyde (MDA) were determined according to Nishikimi, et al., (1972); Cao, et al., (1993) and Ohkawa, et al., (1979), respectively.

\section{Statistical analysis:}

The obtained data were statistically analyzed using computerized SPSS (Statistic Program Sigmastat, Statistical Soft-Ware, SAS Institute, Cary, NC). Effects of different treatments were analyzed by one way ANOVA (Analysis of variance) test using Duncan's multiple range test and $\mathrm{p}<0.05$ was used to indicate significance between different groups as described by Snedecor and Cochran, (1967).

\section{RESULTS \& DISCUSSION}

Table (1) described the chemical composition of wheat flour $(72 \%$ Ex.) which the high in carbohydrate, moisture and protein (74.87, $11.80, \& 10.45 \%)$ respectively. While was low in ash, fat and crude fiber $(00.58,01.19 \&$ $01.11 \%)$ respectively. The content of moringa leaves was carbohydrates, protein, fiber, moisture and ash (42.73, $25.04,15.74,07.57 \& 06.95 \%)$ respectively. In other studies, the high content of protein, ash, fiber and fat in moringa leaves can be seen in the study of Aberra, (2011) and Dubey, et al. (2013).

Data presented in Table (2) illustrated that individually, of moringa leaves contained considerable amount of polyphenolic compounds with dominant components consisting of salicylic (3196.99 ppm), ellagic acid 
Ali Monahi Nazal Al Shammari \& Hanaa F. El-Mehiry

(1682.81 ppm), catechol (1204.49 ppm). Table (2) it can be showed that the types and concentrations of flavonoid compounds in moringa leaves. It indicated that querctin (1965.01 ppm), rosmarinic acid (41.23 ppm) and benzoic (30.49 ppm). In similar studies the chemical composition of moringa leaves that ellagic acid was found to be the predominant constituent

Amaglo et al., (2010) and Mbikay, (2012).

Table (3) showed the results of the effect of flat bread made from wheat flour (control) compared with four types of flat bread after fortification at (10\& 15\%) moringa powder and (5 $\& 10 \mathrm{ml})$ moringa oil. The high content of carbohydrates, moisture and protein were recorded in un-fortified flat bread (35.73, $37.26 \& 19.85$ $\mathrm{g} / 100 \mathrm{~g}$ ) compared with the other types of fortified flat bread (10\& 15\%) with moringa powder and (5 $\& 10 \mathrm{ml})$ moringa oil. This could be due to protein, fat, ash and fiber content of moringa powder and oil. The fortified flat bread with moringa powder and oil levels could have impacts on both quality texture baking processed with a moringa leaves powder, this data reported similar values with in data Table (4) Sensory evaluation. Samples (10\& $15 \%)$ moringa powder and (5 $\& 10 \mathrm{ml}$ ) moringa oil were near to scores of control flat bread. Changes in eating habits starting from the development societies in recent years have led people to search for easier and healthier foods with satisfactory taste and pleasant appearance. Thus, the food industry continually seeks to adapt and develop new formulations designed to increase shelf life and to improve quality and food safety. These results are in harmony with those obtained by Sengev, et al., (2012) and Mona, et al., (2013).

Data recorded in Table (5) illustrated that the positive control rats showed a 
Ali Monahi Nazal Al Shammari \& Hanaa F. El-Mehiry

significant decrease in feed intake and weight gain \% compared to their corresponding normal control group. These results may be attributed to loss of appetite, caused by cisplatin disturbance in the gastric enzymes secretions, changes in the $\mathrm{pH}$ of gastric secretion and alteration in the level of hormone $\mathrm{s}$ in the body. These data are similar to that of Ma, et al., (2007) and Venugopal, et al., (2013). Weight gain \% of all treated groups with fortified flat bread $(10 \& 15 \%)$ moringa powder and $(5 \& 10 \mathrm{ml}$ ) moringa oil significantly increased as compared to the positive control group, this is in agreement with the previous studies done some by Omotesho, et al., (2013) who reported that moringa leaves contain important polyphenolic compounds such as high level of salicylic, querctin and ellagic acid. These results are in parallel with those reported by Mona, et al., (2013) and Saini, et al., (2014). These results may be due to the biochemical properties of moringa powder and oil which acts as antioxidant agent and its pharmacodynamics and pharmacokinetics actions on the against oxidative stress induced by cisplatin.

The effect of moringa powder and oil fortified flat bread on kidney function activities measured in cisplatin-induced nephrotoxicity in rats was presented in Table (6). From these results, there was significant improvement in uric acid, creatinine and urea with moringa powder and oil fortified flat bread. It indicated that it has favourable effect in bringing down the severity induced by cisplatin as in the positive control group. Creatinine, uric acid and urea level were significantly higher in control (+ve) group compared to the normal control group. However treatment with moringa powder and oil fortified flat bread in groups (5 and 6) significantly reduced these 
Ali Monahi Nazal Al Shammari \& Hanaa F. El-Mehiry

parameters compared to treated group 3 (100\% wheat flour).

It appears from our results that high concentration of moringa powder and oil fortified flat bread at $15 \%$ and $10 \mathrm{ml}$ moringa powder and oil fortified flat bread were safe and improves the renal function. The increase in the level of these metabolites uric acid, creatinine and urea in nephrotoxic injury is due to damage of the kidneys and our results may suggest that renal damage associated with cisplatin may cause acute renal failure with single dose. Blood urea and creatinine are considered significant markers of renal dysfunction. These results are in harmony with those obtained by Galea and Murray, (2002) and Mladenovic, et al., (2012). The results of this study indicate a basis for the toxic effects of cisplatin and suggest a possible way of counteracting the toxicity by introducing protective agents such phenolic compounds, other antioxidants in fortified flat bread. It also appears that cells adapt to the effects of cisplatin through the induction of systems. We conclude that moringa powder and oil may be a promising compound for reducing cisplatin-toxic side effects including nephrotoxicity.

Table (7) presented that, (+ve) control rat group showed significant increase in AST, ALT and ALP level compared to (-ve) control group. The groups treated with fortified flat bread with moringa powder and oil reduced the level of AST and ALT with respect to (+ve) control rat group. Another study by Olaleye and Rocha, (2008) reported that cisplatin generally are considered hepatotoxic, cisplatin has been associated with a low rate of serum enzyme liver and steatosis. In another instance, hepatocellular liver injury was described associated to cisplatin.

While groups (5 and 6) showed significant decrease in 
Ali Monahi Nazal Al Shammari \& Hanaa F. El-Mehiry

AST, ALT and ALP compared with group 3 treated with $100 \%$ wheat flour. Similar finding was observed by Alaaeldin and Hamza (2010) who noticed hepatoprotective potential of moringa due to its content of vanillin, sitosterol, 4-hydroxy mullein and octadecanoic acid while alkaloids, waxes, peracetic acid and kaempferol are reported from its flowers which might be due to the presence of vitamin $\mathrm{C}$ and $\mathrm{A}$ which has hepatoprotective effect.

Results in Table (8) demonstrate that there was a significant increase in serum TC, TG, and LDL-c, while the levels of HDL-c significantly lower in (+ve) control rat group than in the negative control group. The groups of rats treated with $100 \%$ wheat flour (G 3) and fortified flat bread with moringa powder and oil (G 4, 5, 6 and 7) had the lowest significant serum TC, TG, and LDL-c compared to the positive control group. On the other hand, all treated groups fortified flat bread with different levels of moringa powder and oil had significantly higher of HDL-c compared with those of the positive control group. The best results in lipid fractions was in the groups treated with fortified moringa powder and oil groups (5 and 6). These results are in harmony, with those obtained by Ghasi et al., (2000). The antioxidant effect of moringa plays a significant role in amelioration of CISinduced renal damage, but the lipid-lowering effect of statins may also be involved in this mechanism. Moringa powder and oil treatment decreased serum cholesterol, LDLcholesterol, and TG level. Therefore, it is possible that lipid accumulation on the renal tubule might be prevented, thereby showing renoprotective effects. The major renoprotective effect of both moringa powder and oil are mediated by normalization of reactive oxygen species production. Mora Lde, et al., 
(2003) and and Mona, et al., (2013).

Results in table (9) indicated that the positive control group showed significant decrease in seurm testosterone (T), follicle stimulating hormone (FSH) and luteinizing hormone (LH) compared to (-ve) control group. Testosterone receptors may be disturbed by cisplatin also and the sex hormones function Stakisaitis, et al., (2010). Previously, it was reported that testosterone enhance oxidative stress in the kidney and accordingly, it promotes kidney toxicity in proximal tubules in animal models He, et al., (2000).

All of the treated groups with $100 \%$ wheat flour (G 3) and fortified flat bread with moringa powder and oil groups showed significant increase in sexual hormonal parameters compared to positive control group. These data may be due to the effects of oxidative stress and dopamine on male sexual function, we hypothesized that moringa oleifera leaves might improve male sexual function induced by stress. The increased sexual performance during the intermission phase might have been due to the suppression of monoamine oxidase-B

and phosphodiesterase type 5 inhibitor activities and increased testosterone. Therefore, M. oleifera is a potential aphrodisiac Pourmorad, et al., (2006) and Prabsattroo, et al., (2012).

As shown in Table (10), the positive control group showed a significant decrease in superoxid dismutase (SOD) and Total antioxidants, while a significant increase in malondialdehyde (MDA) compared to (-ve) control group. It is potential that increased reactive oxygen species (ROS) production in the serum may be responsible for this damage of the organ as reflected by the change in the levels of MDA and activities of SOD in the study. Treatment with $100 \%$ wheat 
flour (G 3) and fortified flat bread with moringa powder and oil showed also significant increase superoxid dismutase (SOD) and Total antioxidants, at treatment with moringa powder and oil fortified flat bread in groups (5 and 6). While insignificant decrease in malondialdehyde (MDA) compared to (+ve) control group. The antioxidative effect is mainly due to the phenolic acids, flavonoids and anthocyanins present in moringa. Free radical scavenging activity is one of the important antioxidant properties because of the deleterious role of free radicals Abdulkarim, et al., (2005).

\section{CONCLUSIONS}

Food industry seeks to develop new formulations designed to improve quality and food safety. As fortified flat bread with moringa oleifera powder and oil may provide a cheap and simple approach for improving sexual function under stressful conditions. However, more research is needed concerning the possible mechanisms action of moringa powder and oil in the determination of Testosterone, Follicle Stimulating Hormone (FSH) and luteinizing hormone (LH) levels. Thus, moringa powder and oil may be used to minimize the toxicity during chemotherapeutic treatment with cisplatin.

\section{REFRECENS}

A.A.C.C., (2000):

American Association of Cereal Chemistry 12th Ed. Pub. By American Association of Cereal Chemistry.Univ. of Fam. St. Paul. Minnesota. USA.

Abd El-Latif, B. M. (1990):

Improvement of some bakery products thesis. Ph.D. F. Tech. Agric. Moshtohor, Zagazig Univ.
Abdulkarim, S.M., Long, K., Lai, O.M., Muhammad, 
S.K.S., and Ghazali, H. M. (2005):

Some physicochemical properties of Moringa oleifera seed oil extracted using solvent and aqueous enzymatic methods. Food Chem. 93(2):253-63.

Aberra, M., (2011):

Comparative assessment on chemical compositions and feeding values of leaves of Moringa stenopetala and Moringa oleifera using in vitro gas production method. Ethiop. J. Appl. Sci. Technol., 2(2):31-41.

Alaaeldin, and Hamza. A. (2010):

Meliorative effects of Moringa oleifera Lam seed extract on liver fibrosis in rats. Food and Chemical Toxicology. Volume
48, Issue 1, Pages 1452.

Asare, G.A., Gyan, B., Bugyei, K., Adjei, S., Mahama, R., Addo, P., Otu-Nyarko, L., Wiredu, E.K., and Nyarko, A. (2012):

Toxicity potentials of the nutraceutical Moringa oleifera at supra-supplementation levels. J Ethnopharmacol. Jan 6; 139(1):265-72.

Atssahin, A., Karrant, I., and Turk, G. (2006): 
Ali Monahi Nazal Al Shammari \& Hanaa F. El-Mehiry

Protective role of lycopene on cisplatin induced changes in spern characteristics, testicular damage and oxidative stressinrats.

Roperod

Toxical,21:42-47.

Babu, R., and Chaudhuri, M., (2005):

Home water treatment by direct filtration with natural Coagulant. Journal of Water and Health 3, 27-30.

Ballester, J., Munoz, M.C., Dominguez, J., Rigau, T., Guinovart, J.J. and Rodriguez, J.E.(2004):

Insulin-dependent diabetes affects testicular function by FSH -linked mechanisms. J.Androl. 25(5): 706-719.

Bartels, H.; Bohemer, M. and Heirli, C. (1972):

Colorimetric kinetic method of creatinine.
Clin. Chem. Acta., 37:

193.

Cao, G., Alessio, H. and Cutler, R. (1993):

Oxygen radical absorbance capacity assay for antioxidants. Free Radic Biol Med.; 14:303-311.

Cleary, J. F. (2007):

The pharmacologic management of cancer pain. J Palliat Med. 10:1369-94.

Coskuner, Y., Karababa, E., and Ercan, R. (1999):

Flat bread production technology. The Journal of Food, 24: 83-97.

Coskuner, Y. and Karababa, E. (2005):

Studies on the quality of Turkish flat breads based on blends of triticale and wheat flour. International Journal of Food Science and 
Technology, 40: 469479.

Dubey, D., Dora, J., Kumar, A. and Gulsan, R. (2013):

A Multipurpose treemoringa oleifera. International Journal of Pharmaceutical and Chemical Sciences, 2(1) Jan-Mar ISSN: 2277. 5005.

Fossati, P. and Principe, L. (1982):

Serum triglycerides determined calorimetrically with an enzyme that produces hydrogen peroxide. Clin. Chem., 28(10): 2077-2080.

Galea, A.M., and Murray, V (2002):

The interaction of cisplatin and analogues with DNA in reconstituted chromatin. Biochim Biophys Acta, 1579, 142-152. Ognjanovic
BI, Djordjevic NZ, Matic MM, Obradovic.

Ghasi, S., Nwobodo, E. and Ofili, J. (2000):

Hypocholesterolemic effects of crude extract of leaf of Moringa oleifera Lam in high fat diet fed Wister rats. Journal of Ethnopharmacology, 69: 21-25.

He, Q., Liang, C.H., and Lippard, S.J. (2000):

Steroid hormones induce HMG1 overexpression and sensitize breast cancer cells to cisplatin and carboplatin. Proc Natl Acad Sci U S A. 97:5768-72.

Hoseney, R. C. (1988):

Principles of Cereal Science and Technology. AACC, Kansas, 378 pp.

Khorshid, A., Emora, M. and Hawas, M. (1989): 
Ali Monahi Nazal Al Shammari \& Hanaa F. El-Mehiry

Production

of

development

balady

bread. Training Center.

General Organization

of Mills, Silos and Backhouses, Arab

Republic of Egypt.

Kind, P. R., and King, E. J. (1954):

Estimation of alkaline phosphatase activity by determination of hydrolyzed phenol with aminoantipyrene. J. Clin. Path.7, 322.

Ma, S.F., Nishikawa, M., Hyoudou, K., Takahashi, R., Ikemura, M., Kobayashi, Y., Yamashita, F., and Hashida, M. (2007):

Combining cisplatin
with cationized
catalase decreases
nephrotoxicity while
improving antitumor
activity. Kidney Int,
2007, 72, 1474-1482.

Mbikay, M. (2012):

Therapeutic potential of moringa oleifera leaves in chronic hyperglycemia and dyslipidemia:

Review.

A

Pharmacol., 3: 24.

Merfort, I., Wary, V.S.M., and Willuhan, G. (1997):

Flavonol triglycerides from seeds of Nigella Sativa. Phetochem. 46(2):359-363.

Mladenovic, J.M., Stajn, A.S., and Saicic, Z.S. (2012):

Lipid peroxidative damage on cisplatin exposure and alterations in antioxidant defense system in rat kidneys: a possible protective effect of selenium. Int $\mathbf{J}$ Mol Sci, 13, 17901803.

Miller, R.P., Tadagavadi, R.K., Ramesh, G., and Reeves, W.B. (2010):

Mechanisms of

Cisplatin nephrotoxicity. Toxins (Basel) 2:2490-518. 
Ali Monahi Nazal Al Shammari \& Hanaa F. El-Mehiry

Molander, A.I. (1960):

$\begin{aligned} & \text { Discernment } \\ & \text { primary } \\ & \text { substances } \\ & \text { taste } \\ & \text { and }\end{aligned}$
judge food, Iowa State
University, Pbility to
U.S.A.

Mona S. Halaby, Eman M. Elmetwaly and Aya A.A. Omar, (2013):

Effect of moringa oleifera on serum lipids and kidney function of hyperlipidemic rats. Journal of Applied Sciences Research, 9(8): 5189-5198.

Mora Lde, O., Antunes, L.M., Francescato, H.D., and Bianchi Mde, L. (2003):

The effects of oral glutamine on cisplatininduced nephrotoxicity in rats. Pharmacol Res. 47:517-22.

Myers, J., and Shetty, N. (2008):

Going beyond efficacy: strategies for cancer pain management. Curr Oncol; 15:S41-9.

Nishikimi, M.; Rao, N. and Yogi, K. (1972):

Colorimetric determination of superoxide dismutase. Biochem. Biophys. Res. Common.; 46: 849-854.

Ohkawa, H., Ohishi, N. and Yagi, K. (1979):

Assay for lipid peroxides in animal tissues by thiobarbituric acid reaction. Anal Bio.; 95: 351-358.

Olaleye, M.T., and Rocha, B.T. (2008):

Acetaminophen-induce $\mathrm{d}$ liver damage in mice: Effects of some medicinal plants on the oxidative defence system. Exp Toxicol Pathol, Epub ahead of print. 476:483. 
Omotesho, K.F. , Sola-Ojo F.E., Fayeye, T.R., Babatunde, R.O., Otunola, G.A., and Aliyu T.H. (2013):

The potential of moringa tree for poverty alleviation and rural development: Review of evidences on usage and efficacy. International Journal of Development and Sustainability. Vol. 2 : 799-813.

Patton, C. and Crouch, S. (1977):

Enzymatic

colorimetric method for determination of urea in serum. Anal. Chem., 49: 464-269.

Pourmorad, F.,

Hosseinimehr, S. J., and Shahabimajd, N. (2006):

Antioxidant activity, phenol and flavonoid contents of some selected Iranian medicinal plants. Afr J. Biotechnol. 5 (11):1142-1145.
Prabsattroo, T., Wattanathorn, J., and Iamsa-ard, S. (2012):

Moringa

oleifera leaves extract attenuates male sexual dysfunction. Am. J Neurosci. 3(1):17-24.

Quail, J. K., G. J. McMaster, J. D. Tomlinson and Wootton, M. (1990):

Effect of baking temperature time conditions and dough thickness on arabic bread quality. Journal of the Science of Food and Agriculture, 53:527-540.

Reeves, P.; Nielsen, F. and Fahey, G. (1993):

AIN-93 Purified Diets for Laboratory Rodents: Final Report of the American Institute of Nutrition Ad Hoc Writing Committee on the Reformulation of the AIN-76A Rodent Diet. J Nutr., 123(11): 1939. 
Reitman, S. and Frankel, S. (1957):

Determination of serum alanine and aspartate

aminotransferases

(ALT \& AST). Clin .Path. Am. J.; 28: 5763.

Roeschlau, P.; Bernt, E. and Gruber, W. (1974):

Enzymatic colorimetric test with lipid clearing factor (LCF) .J. Clin.Chem. \& Clin. Biochem., 12:403-408.

Saini, R. K. Harish, K. V. Prashanth, N., Shetty, P., and Giridhar, P. (2014):

Elicitors, SA and MJ enhance carotenoids and tocopherol biosynthesis and expression of antioxidant related genes in moringa oleifera lam. leaves. Acta Physiologiae Plantarum. Volume 36, Issue 10: 26952704.
Schams, D. and Karg, H. (1969):

Studien über die Spezifität des Radioimmunotests zur Bestimmung des Luteinisierungshormon s im Rinderblut. Hoppe-Seyhr's Zphysiol. Chem. 351, 41.

Sengev, I., Abu, J. and Gernah, D. (2012):

Effect of M. oleifera leaf powder supplementation on the quality characteristics of wheat bread. Intercontinental Journal of Food Science and Nutrition, 1(1): 01-05.

Snedecor, G.W. and W.G. Cochran, (1967):

Statistical Methods. 7 Ed. the Iowa State University Press, Ames, Iowa, U.S.A.

Soliva, C.R., Kreuzer, M., Foid, N., and Foid, G. (2005): 
Ali Monahi Nazal Al Shammari \& Hanaa F. El-Mehiry

Feeding value of whole and extracted Moringa oleifera leaves for ruminants and their effects on ruminal fermentation in vitro. Anim Feed Sci Technol. 118(1-2):4762.

Stakisaitis, D., Dudeniene, G., Jankūnas, R.J., Grazeliene, G., Didziapetriene, J., and Pundziene, B. (2010):

Cisplatin increases urinary sodium excretion in rats:

Gender-related differences. Medicina (Kaunas) 46:45-50.
1,2-Diazole prevents cisplatin-induced nephrotoxicity in experimental rats. Pharmacological Reports. 65: 980.990.

Wilke, T.J. and Utley, D.J. (1987):

Total testosterone, free androgenic index and calculated free testosterone by analog RIA method. Clinc. Chem.;33:1372:1375.

Venugopal, V., Vinod,P., Narayanan, K. and Chandrasekharan (2013): 
Table (1): Chemical composition of wheat flour and moringa leaves ( $\mathrm{g} / \mathrm{100g}$ dry weight basis)

\begin{tabular}{|c|c|c|}
\hline Nutrients & $\begin{array}{c}\text { Wheat flour } \\
(72 \%) \mathrm{gm}\end{array}$ & $\begin{array}{c}\text { Moringa leaves } \\
\text { powder gm }\end{array}$ \\
\hline Moisture & 11.80 & 07.57 \\
\hline Protein & 10.45 & 25.04 \\
\hline Fat & 01.19 & 01.97 \\
\hline Ash & 00.58 & 06.95 \\
\hline Fiber & 01.11 & 15.74 \\
\hline Carbohydrate & 74.87 & 42.73 \\
\hline
\end{tabular}

Table (2): Polyphenolic compounds and flavonoid (ppm) of moringa leaves

\begin{tabular}{|c|c|}
\hline Phenolic compounds & $(\mathrm{ppm})$ \\
\hline Chlorogenic acid & 1037.38 \\
\hline Caffeic acid & 947.61 \\
\hline Catechol & 1204.49 \\
\hline Gallic acid & 111.18 \\
\hline Protocatechuic & 362.54 \\
\hline Ellagic acid & 1682.81 \\
\hline Protocatechuic & 362.54 \\
\hline Vanillic & 193.17 \\
\hline Caffiene & 409.51 \\
\hline Salicylic & 3196.99 \\
\hline E-vanillic & 233.16 \\
\hline Alpha-coumaric & 67.11 \\
\hline Benzoic & 30.49 \\
\hline Rosmarinic acid & 41.23 \\
\hline Querctin & 1965.01 \\
\hline
\end{tabular}


Table (3): Chemical composition of flat bread fortified by various levels of moringa powder and oil ( $\mathrm{g} / \mathrm{100g}$ dry weight basis)

\begin{tabular}{|c|c|c|c|c|c|}
\hline $\begin{array}{c}\text { Chemical } \\
\text { Composition }\end{array}$ & $\begin{array}{c}\text { bread } \\
\text { (control) }\end{array}$ & $\begin{array}{c}\text { Bread } \\
\text { fortified by } \\
\text { moringa } \\
\text { powder } \\
10 \%\end{array}$ & $\begin{array}{c}\text { Bread } \\
\text { fortified } \\
\text { by } \\
\text { moringa } \\
\text { powder } \\
15 \%\end{array}$ & $\begin{array}{c}\text { Bread } \\
\text { fortified } \\
\text { by } \\
\text { moringa } \\
\text { oil 5\% }\end{array}$ & $\begin{array}{c}\text { Bread } \\
\text { fortified } \\
\text { by } \\
\text { moringa } \\
\text { oil 10\% }\end{array}$ \\
\hline Moisture & 17.26 & 15.49 & 14.08 & 27.45 & 28.52 \\
\hline Protein & 19.85 & 22.02 & 23.14 & 20.25 & 21.14 \\
\hline Fat & 2.68 & 01.96 & 02.60 & 3.14 & 3.54 \\
\hline Ash & 2.29 & 01.84 & 02.33 & 2.95 & 2.63 \\
\hline Fiber & 2.19 & 02.23 & 02.60 & 1.60 & 1.92 \\
\hline Carbohydrate & 55.73 & 56.34 & 55.25 & 44.61 & 42.25 \\
\hline
\end{tabular}




\section{Table (4): Sensory evaluation of flat bread fortified by various levels of moringa powder and oil}

\begin{tabular}{|c|c|c|c|c|c|c|c|}
\hline Samples & $\begin{array}{c}\text { Appeara } \\
\text { nce } \\
\text { (20) }\end{array}$ & $\begin{array}{l}\text { Taste } \\
\text { (15) }\end{array}$ & $\begin{array}{l}\text { Odor } \\
\text { (10) }\end{array}$ & $\begin{array}{l}\text { Crumb } \\
\text { color } \\
\text { (10) }\end{array}$ & $\begin{array}{c}\text { Volume } \\
\text { (15) }\end{array}$ & $\begin{array}{c}\text { Texture } \\
\text { (15) }\end{array}$ & $\begin{array}{c}\text { Overall } \\
\text { acceptabil } \\
\text { ity (15) }\end{array}$ \\
\hline $\begin{array}{c}\text { Un-fortified } \\
\text { bread (control) }\end{array}$ & $\begin{array}{c}19.2 \\
\pm \\
0.24^{\mathrm{a}}\end{array}$ & $\begin{array}{l}14.9 \pm \\
0.74^{\mathrm{a}}\end{array}$ & $\begin{array}{l}9.65 \pm \\
0.23^{\mathrm{a}}\end{array}$ & $\begin{array}{l}9.4 \pm \\
0.24^{\mathrm{a}}\end{array}$ & $\begin{array}{l}13.3 \pm \\
0.24^{\mathrm{a}}\end{array}$ & $\begin{array}{l}14.6 \pm \\
0.37^{a}\end{array}$ & $\begin{array}{c}14.78 \pm \\
0.34^{\mathrm{a}}\end{array}$ \\
\hline $\begin{array}{l}\text { fortified bread } \\
\text { by } 10 \% \\
\text { moringa pwder }\end{array}$ & $\begin{array}{l}18.5 \pm \\
1.04^{\mathrm{b}}\end{array}$ & $\begin{array}{l}14.8 \pm \\
0.65^{\text {a }}\end{array}$ & $\begin{array}{l}9.9 \pm \\
0.26^{\mathrm{a}}\end{array}$ & $\begin{array}{l}8.6 \pm \\
1.13^{b}\end{array}$ & $\begin{array}{l}13.0 \pm \\
0.44^{\mathrm{a}}\end{array}$ & $\begin{array}{l}13.5 \pm \\
0.94^{b}\end{array}$ & $\begin{array}{l}14.17 \pm \\
0.28^{a}\end{array}$ \\
\hline $\begin{array}{c}\text { fortified bread } \\
\text { by } 15 \% \\
\text { moringa } \\
\text { powder }\end{array}$ & $\begin{array}{l}17.0 \pm \\
3.11^{\mathrm{b}}\end{array}$ & $\begin{array}{l}13.0 \pm \\
1.11^{\mathrm{b}}\end{array}$ & $\begin{array}{l}8.9 \pm \\
0.26^{\mathrm{a}}\end{array}$ & $\begin{array}{l}9.5 \pm \\
0.23^{a}\end{array}$ & $\begin{array}{l}12.7 \pm \\
0.56^{b}\end{array}$ & $\begin{array}{l}14.8 \pm \\
0.44^{\mathrm{a}}\end{array}$ & $\begin{array}{c}14.53 \pm \\
0.34^{\mathrm{a}}\end{array}$ \\
\hline $\begin{array}{c}\text { fortified bread } \\
\text { by } 5 \% \\
\text { moringa oil }\end{array}$ & $\begin{array}{l}18.0 \pm \\
1.43^{b}\end{array}$ & $\begin{array}{l}14.7 \pm \\
0.63^{\mathrm{a}}\end{array}$ & $\begin{array}{l}8.5 \pm \\
0.25^{\mathrm{a}}\end{array}$ & $\begin{array}{l}9.3 \pm \\
0.42^{\text {a }}\end{array}$ & $\begin{array}{l}11.2 \pm \\
0.94^{c}\end{array}$ & $\begin{array}{l}14.2 \pm \\
0.54^{\mathrm{a}}\end{array}$ & $\begin{array}{c}14.46 \pm \\
0.33^{a}\end{array}$ \\
\hline $\begin{array}{c}\text { fortified bread } \\
\text { by } 10 \% \\
\text { moringa oil }\end{array}$ & $\begin{array}{l}17.0 \pm \\
3.10^{b}\end{array}$ & $\begin{array}{l}14.7 \pm \\
0.62^{a}\end{array}$ & $\begin{array}{l}7.5 \pm \\
0.11^{b}\end{array}$ & $\begin{array}{l}9.11 \pm \\
0.26^{\mathrm{a}}\end{array}$ & $\begin{array}{l}11.7 \pm \\
0.54^{c}\end{array}$ & $\begin{array}{l}14.9 \pm \\
0.71^{\mathrm{a}}\end{array}$ & $\begin{array}{l}14.89 \pm \\
0.34^{\mathrm{a}}\end{array}$ \\
\hline
\end{tabular}

Values in each column which have different letters are significantly different $(p<0.05)$. 
Table (5): Effect of flat bread and that fortified with moringa powder and oil on feed intake and body weight gain $\%$ in rats

\begin{tabular}{|l|c|c|}
\hline Parameters & $\begin{array}{c}\text { Feed intake } \\
\text { g/day/rat }\end{array}$ & Body weight gain \\
Groups & & $\%$ \\
\hline Group1 (-ve) & $15.67 \pm$ & $23.67 \pm$ \\
& $0.817^{\mathrm{a}}$ & $1.54^{\mathrm{a}}$ \\
\hline Group 2 (+ve) & $11.33 \pm$ & $17.37 \pm$ \\
& $0.585^{\mathrm{c}}$ & $0.97^{\mathrm{d}}$ \\
\hline Group 3 & $14.67 \pm$ & $19.88 \pm$ \\
& $0.605^{\mathrm{b}}$ & $1.496^{\mathrm{b}}$ \\
\hline Group 4 & $14.75 \pm$ & $24.27 \pm$ \\
& $0.758^{\mathrm{b}}$ & $1.246^{\mathrm{c}}$ \\
\hline Group 5 & $14.51 \pm$ & $34.99 \pm$ \\
& $0.615^{\mathrm{b}}$ & $0.995^{\mathrm{b}}$ \\
\hline Group 6 & $14.60 \pm \pm$ & $36.01 \pm$ \\
& $1.67^{\mathrm{b}}$ & $2.91^{\mathrm{b}}$ \\
\hline Group 7 & $14.40 \pm$ & $45.40 \pm$ \\
& $1.67^{\mathrm{b}}$ & $1.67^{\mathrm{b}}$ \\
\hline
\end{tabular}

Values in each column which have different letters are significantly different $(p<0.05)$. 


\section{Table (6): Effect of flat bread and that fortified with moringa} powder and oil on kidney function in rats

\begin{tabular}{|c|c|c|c|}
\hline Parameters & $\begin{array}{c}\text { Uric acid } \\
\mathrm{mg} / \mathrm{dl}\end{array}$ & $\begin{array}{c}\text { Creatinine } \\
\mathrm{mg} / \mathrm{dl}\end{array}$ & $\begin{array}{c}\text { Urea } \\
\mathrm{mg} / \mathrm{dl}\end{array}$ \\
\hline Groups & & $2.53 \pm$ & $1.16 \pm$ \\
\hline Group1 (-ve) & $0.78^{\mathrm{e}}$ & $1.18 \mathrm{e}$ & $27.88 \pm$ \\
& $5.20 \pm$ & $5.62 \pm$ & $39.93 \pm$ \\
\hline Group 2 (+ve) & $0.52^{\mathrm{a}}$ & $2.47^{\mathrm{a}}$ & $3.20^{\mathrm{a}}$ \\
\hline Group 3 & $3.79 \pm$ & $3.87 \pm$ & $34.14 \pm$ \\
& $0.72^{\mathrm{b}}$ & $1.32^{\mathrm{b}}$ & $3.29^{\mathrm{b}}$ \\
\hline Group 4 & $2.82 \pm$ & $2.83 \pm$ & $31.17 \pm$ \\
& $0.57^{\mathrm{c}}$ & $1.25^{\mathrm{c}}$ & $3.59^{\mathrm{c}}$ \\
\hline Group 5 & $2.72 \pm$ & $2.72 \pm$ & $30.21 \pm$ \\
& $0.93^{\mathrm{d}}$ & $1.15^{\mathrm{d}}$ & $3.43^{\mathrm{d}}$ \\
\hline Group 6 & $2.65 \pm$ & $2.65^{\mathrm{d}} \pm$ & $31.90 \pm$ \\
& $0.14^{\mathrm{d}}$ & $0.13^{\mathrm{c}}$ & $2.38^{\mathrm{c}}$ \\
\hline Group 7 & $2.91 \pm$ & $2.89 \pm$ & $34.39 \pm$ \\
& $0.16^{\mathrm{c}}$ & $0.17^{\mathrm{d}}$ & $4.48^{\mathrm{b}}$ \\
\hline
\end{tabular}

Values in each column which have different letters are significantly different $(p<0.05)$. 
Ali Monahi Nazal Al Shammari \& Hanaa F. El-Mehiry

\section{Table (7): Effect of flat bread and that fortified with moringa} powder and oil on the activity of liver enzymes in rats

\begin{tabular}{|c|c|c|c|}
\hline $\begin{array}{c}\text { Parameters } \\
\text { Groups }\end{array}$ & $\begin{array}{c}\text { AST } \\
(\mathrm{Iu} / \mathrm{l})\end{array}$ & $\begin{array}{c}\text { ALT } \\
(\mathrm{Iu} / \mathrm{l})\end{array}$ & $\begin{array}{c}\text { ALP } \\
(\mathrm{Iu} / \mathrm{l})\end{array}$ \\
\hline Group1 (-ve) & $53.80 \pm 2.11^{\mathrm{e}}$ & $25.21 \pm 1.78^{\mathrm{e}}$ & $66.26 \pm 3.97^{\mathrm{e}}$ \\
\hline Group 2 (+ve) & $93.57 \pm 5.58^{\mathrm{a}}$ & $52.86 \pm 3.27^{\mathrm{a}}$ & $114.39 \pm 6.49^{\mathrm{a}}$ \\
\hline Group 3 & $89.86 \pm 4.75^{\mathrm{b}}$ & $44.76 \pm 3.13^{\mathrm{b}}$ & $99.33 \pm 3.65^{\mathrm{b}}$ \\
\hline Group 4 & $79.08 \pm 4.28^{\mathrm{c}}$ & $42.03 \pm 3.43^{\mathrm{b}} \mathrm{c}$ & $86.74 \pm 5.649^{\mathrm{c}}$ \\
\hline Group 5 & $66.82 \pm 3.02^{\mathrm{d}}$ & $39.75 \pm 2.14^{\mathrm{c}}$ & $72.89 \pm 2.622^{\mathrm{e}}$ \\
\hline Group 6 & $69.08 \pm 4.28^{\mathrm{d}}$ & $37.83 \pm 3.43^{\mathrm{d}}$ & $76.74 \pm 5.649^{\mathrm{d}}$ \\
\hline Group 7 & $79.82 \pm 3.02^{\mathrm{c}}$ & $39.69 \pm 2.14^{\mathrm{c}}$ & $91.86 \pm 2.622^{\mathrm{b}}$ \\
\hline
\end{tabular}

Values in each column which have different letters are significantly different $(p<0.05)$.

AST: Aspartate aminotransferase. $\quad$ ALT: Alanine aminotransferase phosphatase

\section{Table (8): Effect of flat bread and that fortified with moringa powder and oil on serum lipid profile in rats}

\begin{tabular}{|c|c|c|c|c|}
\hline Parameters & $\begin{array}{c}\text { TC } \\
\mathrm{mg} / \mathrm{dl}\end{array}$ & $\begin{array}{c}\text { TG } \\
\mathrm{mg} / \mathrm{dl}\end{array}$ & $\begin{array}{c}\text { HDL-c } \\
\mathrm{mg} / \mathrm{dl}\end{array}$ & $\begin{array}{c}\text { LDL-c } \\
\mathrm{mg} / \mathrm{dl}\end{array}$ \\
\hline Groups & & & & \\
\hline Group1 (-ve) & $101.21 \pm 24.33^{\mathrm{f}}$ & $51.03 \pm 12.62^{\mathrm{f}}$ & $36.86 \pm 3.11^{\mathrm{a}}$ & $59.75 \pm 13.43 \mathrm{e}$ \\
\hline Group 2 (+ve) & $146.19 \pm 27.12^{\mathrm{a}}$ & $129.43 \pm 24.82^{\mathrm{a}}$ & $24.58 \pm 2.54^{\mathrm{d}}$ & $129.12 \pm 23.43^{\mathrm{a}}$ \\
\hline Group 3 & $126.27 \pm 26.54^{\mathrm{b}}$ & $101.27 \pm 23.03^{\mathrm{b}}$ & $34.97 \pm 2.66^{\mathrm{b}}$ & $88.06 \pm 11.37^{\mathrm{b}}$ \\
\hline Group 4 & $117.14 \pm 27.65^{\mathrm{c}}$ & $86.17 \pm 24.34^{\mathrm{c}}$ & $33.60 \pm 1.93^{\mathrm{b}}$ & $67.46 \pm 12.36^{\mathrm{c}}$ \\
\hline Group 5 & $105.48 \pm 4.28^{\mathrm{d}}$ & $64.324 \pm 3.083^{\mathrm{e}}$ & $32.02 \pm 2.76^{\mathrm{c}}$ & $62.58 \pm 1.76^{\mathrm{d}}$ \\
\hline Group 6 & $103.27 \pm 4.54 \mathrm{e}^{\mathrm{e}}$ & $56.194 \pm 3.456^{\mathrm{f}}$ & $31.97 \pm 2.75^{\mathrm{cd}}$ & $61.06 \pm 0.37^{\mathrm{d}}$ \\
\hline Group 7 & $110.48 \pm 19.31^{\mathrm{d}}$ & $74.19 \pm 12.05^{\mathrm{d}}$ & $33.39 \pm 2.08^{\mathrm{b}}$ & $63.78 \pm 14.06^{\mathrm{c}}$ \\
\hline
\end{tabular}

Values in each column which have different letters are significantly different ( $p<0.05)$.
TC: Total Cholesterol.
TG: Triglycerides.
HDL-c: High density lipoprotein.
LDL-C: Low density lipoprotein. 
Amelioration of Cisplatin Induced Sexual Toxicity on Male Rats by Using

Fortified of Flat Bread with Moringa Oleifera

Ali Monahi Nazal Al Shammari \& Hanaa F. El-Mehiry

Table (9): Effect of flat bread and that fortified with moringa powder and oil on sexual hormonal parameters in rats

\begin{tabular}{|c|c|c|c|}
\hline & Parameters & FSH & LH \\
Groups & $\mathrm{ng} / \mathrm{mL}$ & $\mathrm{ng} / \mathrm{mL}$ & $\mathrm{ng} / \mathrm{mL}$ \\
\hline Group 1 (-ve) & $25.2 \pm 1.7^{\mathrm{a}}$ & $150.38 \pm 0.75^{\mathrm{a}}$ & $4.47 \pm 0.76^{\mathrm{a}}$ \\
\hline Group 2 (+ve) & $12.03 \pm 2.01^{\mathrm{e}}$ & $91.17 \pm 0.55^{\mathrm{e}}$ & $1.35 \pm 1.16^{\mathrm{e}}$ \\
\hline Group 3 & $17.12 \pm 13.01^{\mathrm{d}}$ & $119.98 \pm 0.65^{\mathrm{d}}$ & $2.22 \pm 0.96^{\mathrm{c}}$ \\
\hline Group 4 & $19.33 \pm 14.81^{\mathrm{c}}$ & $129.42 \pm 0.80^{\mathrm{c}}$ & $2.47 \pm 0.52^{\mathrm{b}}$ \\
\hline Group 5 & $21.01 \pm 14.10^{\mathrm{b}}$ & $134.61 \pm 0.09^{\mathrm{b}}$ & $2.54 \pm 0.37^{\mathrm{b}}$ \\
\hline Group 6 & $22.81 \pm 19.64^{\mathrm{b}}$ & $135.59 \pm 0.80^{\mathrm{b}}$ & $2.59 \pm 0.96^{\mathrm{b}}$ \\
\hline Group 7 & $23.25 \pm 28.3^{\mathrm{b}}$ & $132.73 \pm 0.68^{\mathrm{b}}$ & $3.48 \pm 0.52^{\mathrm{b}}$ \\
\hline
\end{tabular}

Values in each column which have different letters are significantly different $(p<0.05)$.

T: testosterone. FSH: Follicle Stimulating Hormone levels $\quad$ LH: Luteinizing hormone

Table (10): Effect of feeding flat bread compatible moringa on antioxidant parameters in rats

\begin{tabular}{|c|c|c|c|}
\hline Parameters & $\begin{array}{c}\text { Superoxide } \\
\text { dismutase } \\
\mathrm{U} / \mathrm{mL}\end{array}$ & $\begin{array}{c}\text { Total } \\
\text { antioxidants } \\
\mathrm{mmol} / \mathrm{L}\end{array}$ & $\begin{array}{c}\text { Malondialdehyd } \\
\mathrm{e} \\
\mathrm{mmol} / \mathrm{L}\end{array}$ \\
\hline Group1 (-ve) & $176.23 \pm 12.74^{\mathrm{a}}$ & $3.38 \pm 0.75^{\mathrm{a}}$ & $4.47 \pm 0.76 \mathrm{e}$ \\
\hline Group 2 (+ve) & $114.33 \pm 12.01^{\mathrm{d}}$ & $1.17 \pm 0.55^{\mathrm{d}}$ & $12.35 \pm 1.16^{\mathrm{a}}$ \\
\hline Group 3 & $142.12 \pm 13.01^{\mathrm{c}}$ & $1.98 \pm 0.65^{\mathrm{c}}$ & $7.21 \pm 0.96^{\mathrm{c}}$ \\
\hline Group 4 & $148.33 \pm 14.81^{\mathrm{bc}}$ & $2.58 \pm 0.80^{\mathrm{b}}$ & $6.37 \pm 0.52^{\mathrm{b}}$ \\
\hline Group 5 & $156.01 \pm 14.10^{\mathrm{b}}$ & $2.61 \pm 0.09^{\mathrm{b}}$ & $6.11 \pm 0.37^{\mathrm{b}}$ \\
\hline Group 6 & $159.81 \pm 19.64^{\mathrm{b}}$ & $2.69 \pm 0.80^{\mathrm{b}}$ & $6.21 \pm 0.96^{\mathrm{b}}$ \\
\hline Group 7 & $147.25 \pm 28.3^{\mathrm{c}}$ & $2.59 \pm 0.68^{\mathrm{b}}$ & $6.47 \pm 0.52^{\mathrm{b}}$ \\
\hline
\end{tabular}

Values which don't share the same letter in each column are significantly different. 


\section{تحسين السمية الجنسية الناتجه عن السيسبلاتين بخبز

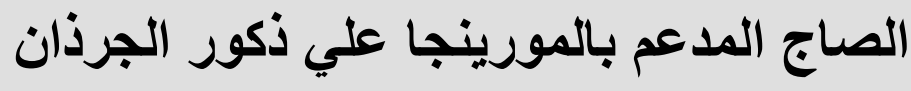 \\ على مناحى نزال الثمرى' و هناء فاروق المهيري ' \\ 'قتم الاقتصاد المنزلي ـ كلية التربية الاساسية ـالهئية العامة للتعليم التطبيقى و التدريبـ الكويت

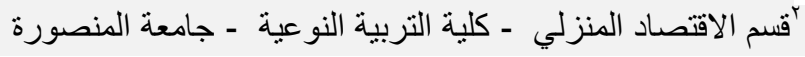

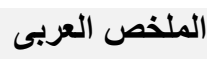

تهجف هذه الدراسة الى تأثبر تدعيم خبز الصاج بالمورينجا على السمبة الجنسبة الناتجة عن

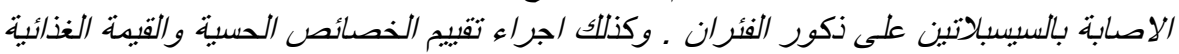

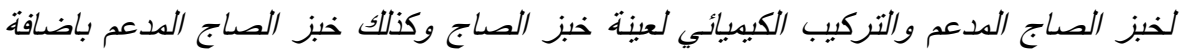

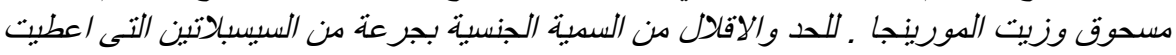

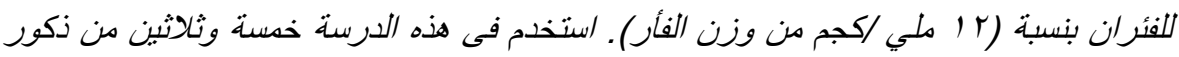

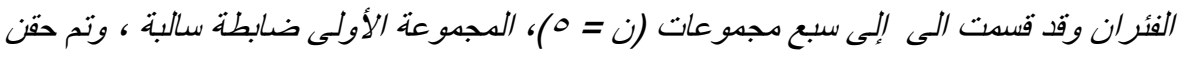

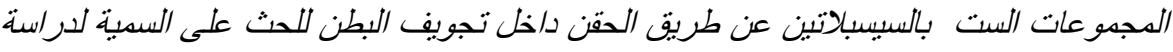

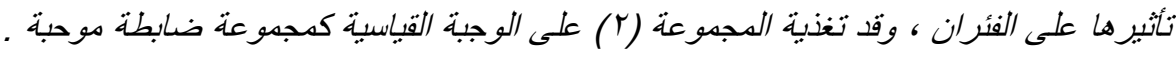

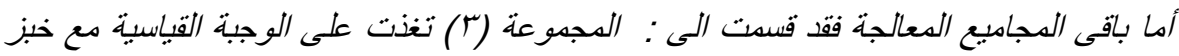

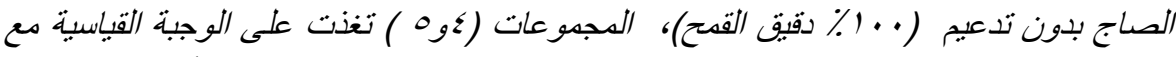

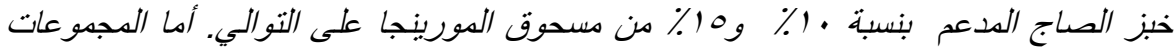

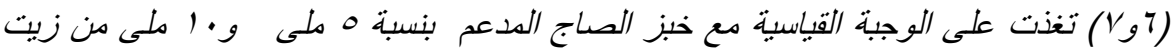

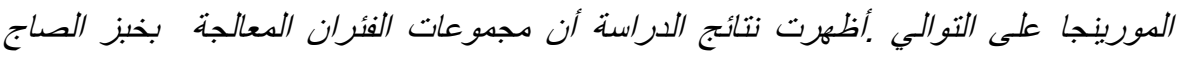

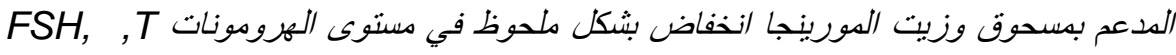
LH

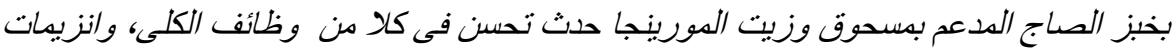

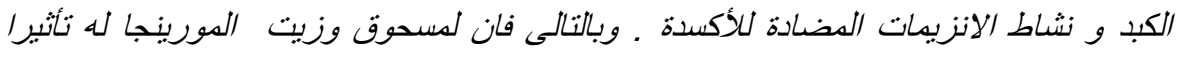

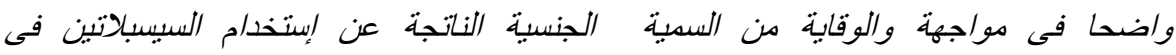

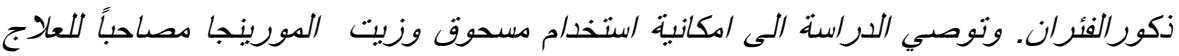
بالسبيسباتنين. الكلمات المفتاحية: المورنجا ـ السبسبلاتين - التسمع للجنسيه- وتسمم الكلى 